\title{
Immunohistochemical Analysis of Proliferating Cell Nuclear Antigen (PCNA) in Dental Follicles of Impacted Third Molars
}

\author{
Análisis Imunohistoquímico de Antígeno de Proliferación Celular Nuclear (PCNA) \\ en Folículos Dentales de los Terceros Molares Retenidos
}

"David Moraes de Oliveira; ${ }^{* *}$ Márcia Maria Ferreira da Silveira; ${ }^{* *}$ Emanuel Sávio de Souza Andrade; **Ana Paula Veras Sobral; ${ }^{* * *}$ Paulo Ricardo Saquete Martins-Filho; ${ }^{* * * *}$ Thiago de Santana Santos \& ${ }^{* * * * *}$ Patrícia Leimig Amorim de Oliveira

\begin{abstract}
OLIVEIRA, D. M.; SILVEIRA, M. M. F.; ANDRADE, E. S. S.; SOBRAL, A. P. V.; MARTINS-FILHO, P. R. S.; SANTOS, T. S. \& OLIVEIRA, P. L. A. Immunohistochemical analysis of proliferating cell nuclear antigen (PCNA) in dental follicles of impacted third molars. Int. J. Morphol., 29(2):526-531, 2011.
\end{abstract}

SUMMARY: This study investigated the immunodetection of PCNA in epithelial components of dental follicles associated with impacted third molars without radiographical and morphological signs of pathosis. A total of 105 specimens of dental follicles associated with impacted third molars with incomplete rhizogenesis (between Nolla's stage 6 and 9) were surgically removed from 56 patients. Epithelial cell proliferating was determined by using immunohistochemical labeling. Statistical analysis was performed using the Fisher exact test. Of the 105 dental follicles collected, 6 were PCNA-positive $(\approx 6 \%)$. The specimens with squamous metaplasia and epithelial hyperplasia had higher rates of positivity for PCNA, as well as those with proliferative remnants of odontogenic epithelium. In conclusion, this study shows that dental follicles at this stage of development have low proliferative potential, but suggests that squamous metaplasia, hyperplasia of the epithelial lining and presence of proliferative odontogenic epithelial rests in the connective tissue may be early signs of developing lesions of odontogenic origin.

KEY WORDS: Immunohistochemistry; Dental Sac; Third Molar.

\section{INTRODUCTION}

The dental follicle (DF) is an ectomesenchymal tissue that surrounds the developing tooth germ and contains precursor cells for cementoblasts, periodontal ligament and osteoblasts. Odontogenic epithelial components of DF are crucial to the development of odontogenic cysts and tumors. Thus, proliferation potential of these components needs to be better analyzed through the use of molecular markers, such as PCNA (Proliferating Cell Nuclear Antigen).

PCNA is a protein that exists in cell nuclei that plays a critical role in DNA replication and the initiation of cell proliferation. This protein has been detected immunohistochemically in odontogenic lesions (Li et al., 1994; El Murtadi et al., 1996; Piattelli et al., 1998; de Paula et al., 2000; Meer et al., 2003; Barboza et al., 2005), but there are not much literature data concerning the PCNA in DF (Adelsperger et al., 2000).
The aim of this study was to investigate the immunodetection of PCNA in epithelial components of DF associated with impacted third molars without radiographical and morphological signs of pathosis.

\section{MATERIAL AND METHOD}

The sample consisted of DF associated with impacted third molars with incomplete rhizogenesis (between 6 and 9 Nolla's stages of tooth calcification) without obvious clinical and radiographical signs of pathosis. The DF were taken from 56 patients, of whom 17 $(30 \%)$ were males and $39(70 \%)$ were females. Age ranged from 13 to 24 years, with a mean of 18.3 years $(\mathrm{SD}=2.7$ years) and median of 18 years.

* Maurício de Nassau Faculty, Recife, Brazil.

*** Estácio Faculty of Sergipe, Aracaju, Brazil.

**** Department of Oral Pathology, School of Dentistry, Federal University of Sergipe, Aracaju, Brazil.

***** Department of Oral and Maxillofacial Surgery, Ribeirão Preto School of Dentistry, University of São Paulo, Ribeirão Preto, Brazil.

****** Department of Esthetics, School of Dentistry, University of Pernambuco, Aracaju, Brazil. 
Panoramic radiographies were taken for all the patients (Fig 1). The contours of the tooth and of the pericoronal space were traced on ultraphan paper using the X-ray viewer. The widest point of the pericoronal space was measured using a graduated scale. Subjects who had pericoronal space $>4.0 \mathrm{~mm}$ were excluded from the study.

The follicles were separated from the tooth by making an incision at the level of the cementoenamel junction (Fig 2), conditioned in $10 \%$ formol and routinely stained with hematoxylin and eosin (HE). The epithelial lining of the specimens were classified according to the type (absent, enamel reduced and stratified squamous) and cell activity (inactive and hyperplastic). It was considered inactive in the presence of less than 20 layers of epithelial cells and in the absence of epithelial projections into the connective tissue. It was considered hyperplastic when there were over 20 layers or epithelial projections. The remaining epithelium in the connective tissue was classified as absent, inactive or proliferative. It was inactive when exhibiting a typical island or string formation and proliferative when forming sheets or layers of cells (Oliveira et al., 2008).

Immunohistochemical staining was performed using the streptavidin-biotin method. Briefly, after the $3 \mathrm{~mm}$ sections were deparaffinized in xylene and dehydrated in ethanol, endogenous peroxidase activity was blocked by incubating sections for $15 \mathrm{~min}$ in $0.3 \%$ ( $\mathrm{vol} / \mathrm{vol}$ ) hydrogen peroxide in methanol. Sections were then heated in citrate buffer ( $10 \mathrm{mM}, \mathrm{pH} 6.0)$ at $120^{\circ} \mathrm{C}$ for $1 \mathrm{~min}$ (pressure cooker) to antigen retrieval. The sections were then incubated with primary antibodies to PCNA (Dako A/S, Glostrup, Denmark) for $60 \mathrm{~min}$ at room temperature and then stained according to the streptavidin-biotin method. The immunoreaction was visualized with diaminobenzedine (Dako Corporation, Carpinteria, CA, USA) as a chromogen. The slides were counterstained with Mayer's hematoxylin solution and mounted in Entellan (Merck KGaA, Darmstadt, Germany). For negative control the primary antibody was omitted and as positive control sections of oral squamous cell carcinoma were used. Clear brown nuclei, regardless of staining intensity, were considered PCNA-positive.

Statistical analysis was performed using the Fisher exact test. This work was previously submitted and approved by ethical committee in research from Pernambuco University by number 220/03.

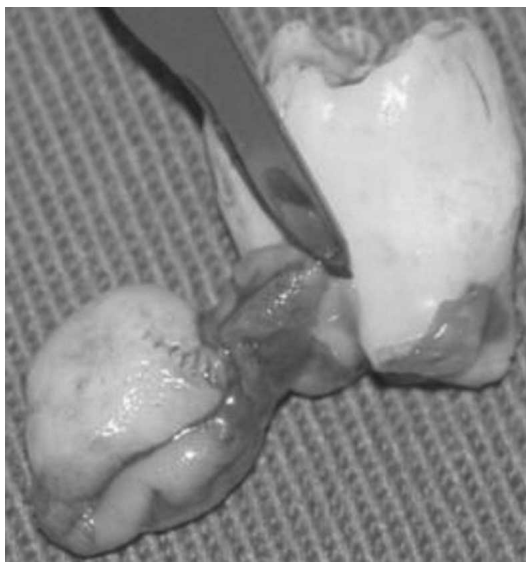

Fig. 2. Morphological aspect of the dental follicle associated to the lower third molar of the right side showed in Fig. 1.

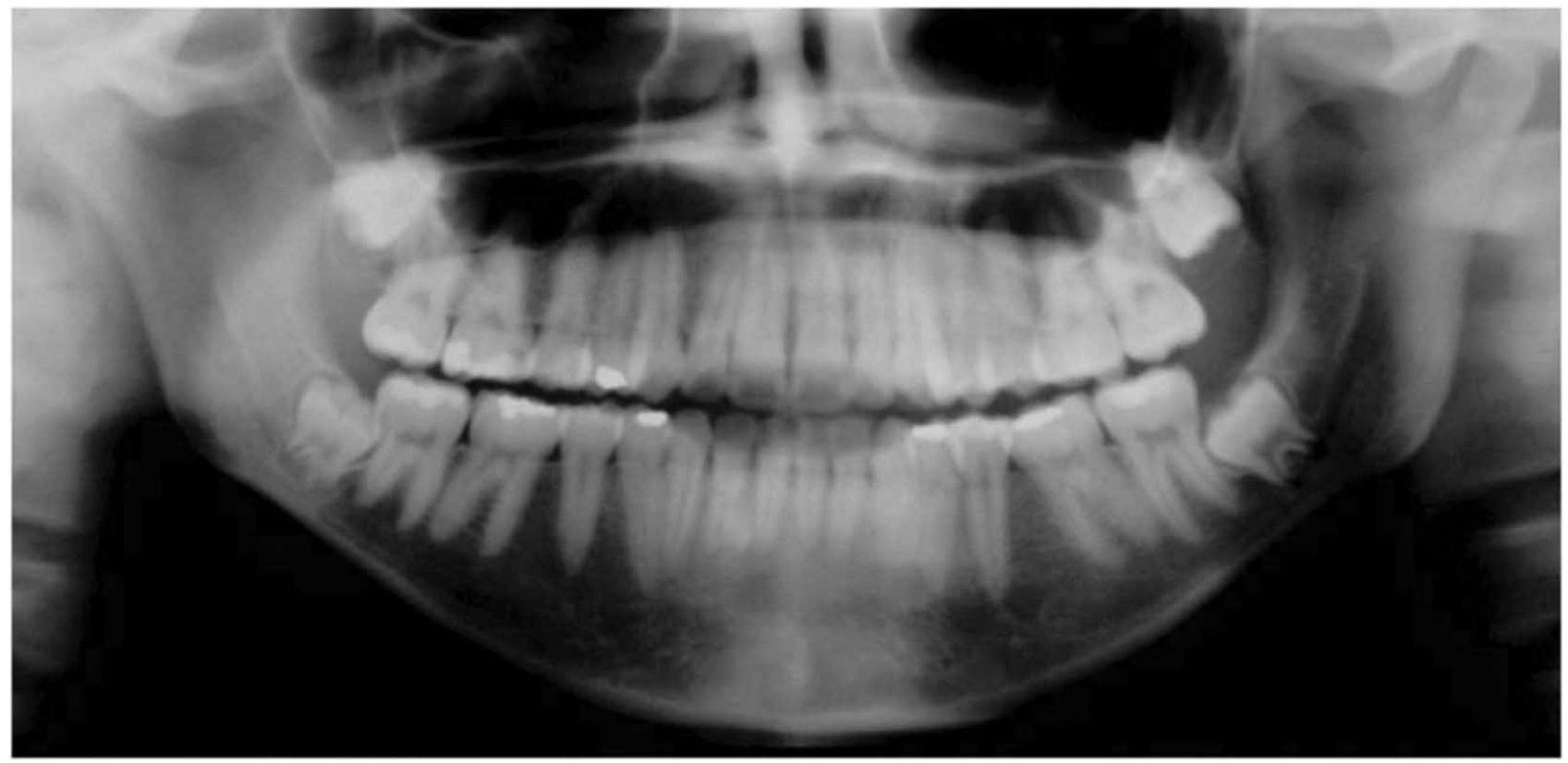

Fig 1. Ortopantomography showing the lower third molars with one third of root completed (Nolla's stage 7). 
OLIVEIRA, D. M.; SILVEIRA, M. M. F.; ANDRADE, E. S. S.; SOBRAL, A. P. V.; MARTINS-FILHO, P. R. S.; SANTOS, T. S. \& OLIVEIRA, P. L. A. Immunohistochemical analysis of proliferating cell nuclear antigen (PCNA) in dental follicles of impacted third molars. Int. J. Morphol., 29(2):526-531, 2011.

\section{RESULTS}

105 DF were assessed for histological and immunohistochemical examination. In relation to epithelial lining, 24 showed no epithelial lining, 66 presented reduced enamel epithelium and 15 stratified squamous epithelium (squamous metaplasia). A higher frequency of DF with squamous metaplasia was observed in 8 and 9 Nolla's stages. Hyperplastic activity was observed in 14 cases, of which $64 \%$ were found in stratified squamous epithelium. Proliferative odontogenic epithelial rests in the connective tissue were found in 5 cases (Fig 3).
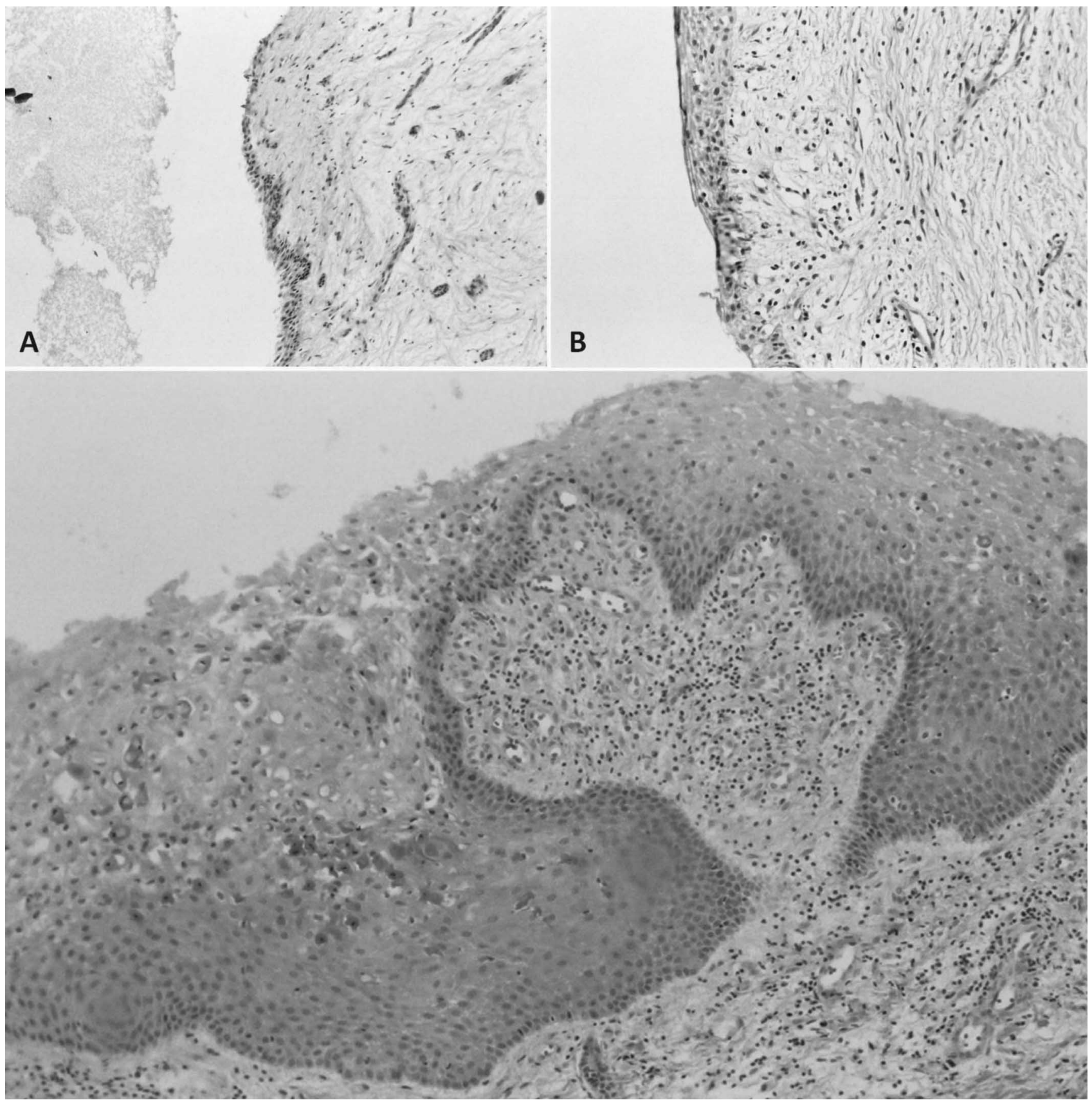

Fig 3. Histological features of the dental follicles (hematoxylin-eosin staining). (A) Inactive enamel reduced epithelium (original magnification $\times 100$ ). (B) Inactive stratified squamous epithelium (original magnification x200). (C) Dental follicle exhibiting hyperplastic stratified squamous epithelium with islands of inactive odontogenic epithelium in the connective tissue (original magnification $\mathrm{x} 100$ ). 
OLIVEIRA, D. M.; SILVEIRA, M. M. F.; ANDRADE, E. S. S.; SOBRAL, A. P. V; MARTINS-FILHO, P. R. S.; SANTOS, T. S. \& OLIVEIRA, P. L. A. Immunohistochemical analysis of proliferating cell nuclear antigen (PCNA) in dental follicles of impacted third molars. Int. J. Morphol., 29(2):526-531, 2011.

Immunohistochemical analysis revealed positivity for PCNA in $6 \mathrm{DF}(\approx 6 \%)$. Three cases were excluded due to problems in the antigen retrieval. A higher frequency of PCNA-positive cases was found in DF with squamous metaplasia, hyperplastic activity and proliferative odontogenic epithelial rests in the connective tissue, but no statistical association was observed (Fig. 4).
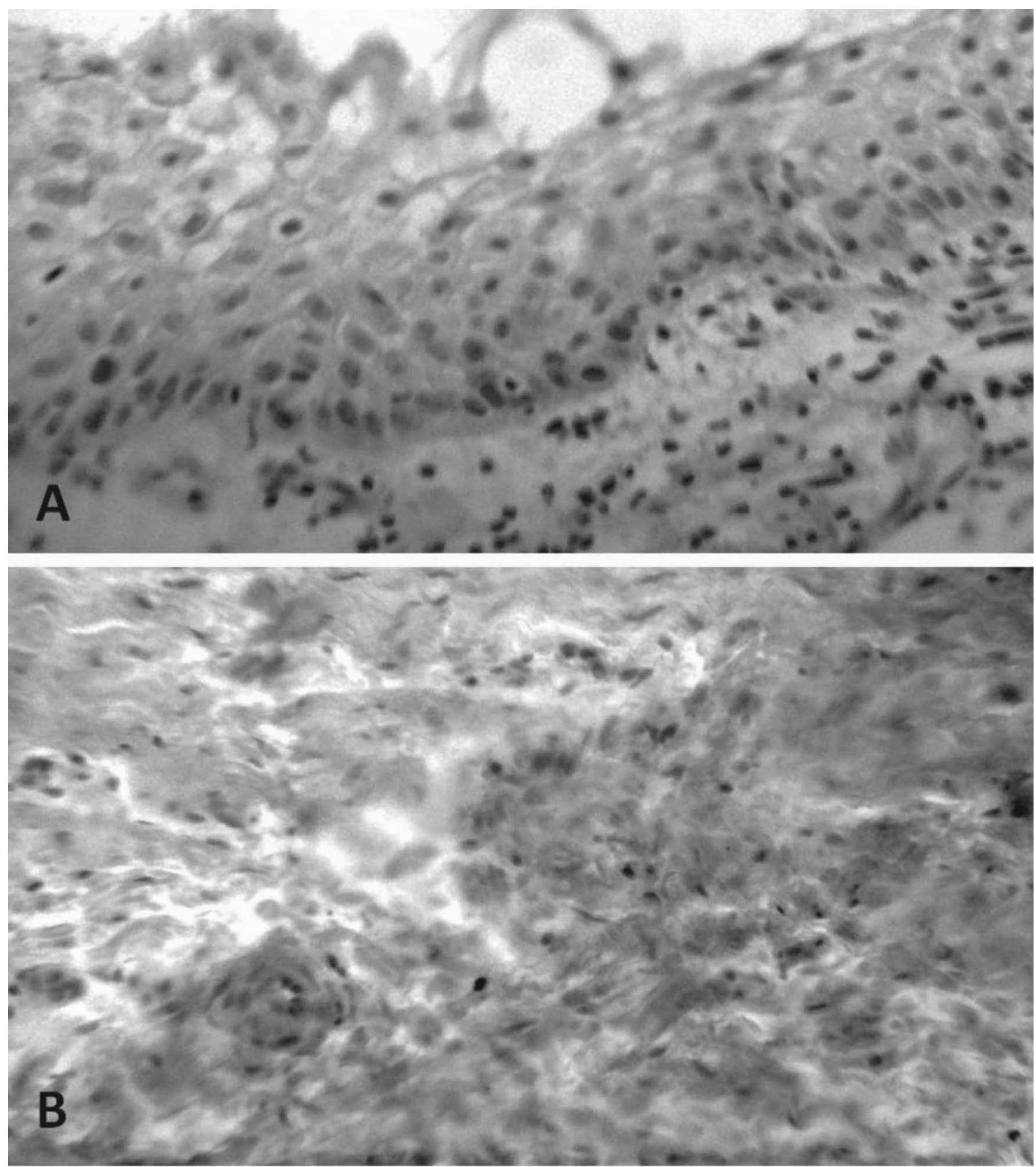

Fig 4. Immunohistochemical staining of the dental follicles (SABC staining). (A) PCNA positive nuclei indicative of proliferative activity in the stratified squamous epithelium (original magnification $\mathrm{x} 400$ ). (B) PCNA positive nuclei in remnants of odontogenic epithelium in the connective tissue (original magnification $\mathrm{x} 400$ ). 


\section{DISCUSSION}

Removal of impacted third molars is a common procedure in oral surgery. Alterations in the expression of proteins related to cell proliferation and apoptosis are a strong indicator of the malignant transformation potential of a certain lesion (Sousa et al., 2009). Thus, in the presence of pathological changes and/or severe symptoms, such as infection, non-restorable carious lesions, cysts, tumors and destruction of adjacent teeth and bone, there are no doubts about the real need for removal of these teeth. However, the justification for prophylactic removal of impacted third molar is less certain and has been debated for many years (NHS Centre for Reviews and Dissemination, 1999).

Although several authors have reported that the risk of the development of cysts and tumors around third molars is extremely low (Stephens et al., 1989; Kostopoulou et al., 2000; Güven et al., 2000), others observed a high incidence of pathological changes in the DF, especially associated with the dentigerous cyst (DC) (Daley \& Wysocki, 1995; Glosser \& Campbell, 1999; Baykul et al., 2005). However, the discrepancy in the incidence rates of pathological changes in the DF is due to lack of standardization in the methods of these studies that used different parameters for radiographic and histological analysis of the cases.

Few authors have studied the proliferative potential of the DF associated to the impacted third molars using immunohistochemical methods. The use of cell proliferating markers, such as integrins (Godoy et al., 2007), Ki-67 (Edamatsu et al., 2005; Cabbar et al., 2008) and PCNA (Adelsperger et al.), has shown that the squamous metaplasia would be the first visible sign of cystic transformation of the DF and not a normal change due to advanced age. In our study, although we have not found a statistical association between PCNA labeling and the type of epithelial lining, probably due to the low number of PCNA-positive cells, the specimens with squamous metaplasia had higher rates of positivity for PCNA than DF with reduced enamel epithelium. Our results suggest that these follicles with squamous metaplasia could represent, at this stage of rhizogenesis, early signs of development of odontogenic lesions. On other hand, there is no way to predict that PCNAnegative follicles remain unchanged if they are left in situ.

Our results also indicate a higher rate of PCNApositive cells in the presence of epithelial hyperplasia, in agreement with the findings of Edamatsu et al., who found a high proliferative potential of follicles with proliferating rete processes through the use of Ki-67.

In conclusion, this study shows that DF at this stage of development have low proliferative potential, but suggests that squamous metaplasia, hyperplasia of the epithelial lining and presence of proliferative odontogenic epithelial rests in the connective tissue may be early signs of developing lesions of odontogenic origin.

ACKNOWLEDGEMENTS. We are thankful to CNPq and CAPES for financial support to execute this study.

OLIVEIRA, D. M.; SILVEIRA, M. M. F.; ANDRADE, E. S. S.; SOBRAL, A. P. V.; MARTINS-FILHO, P. R. S.; SANTOS, T. S. \& OLIVEIRA, P. L. A. Análisis imunohistoquímico de antígeno de proliferación celular nuclear (PCNA) en folículos dentales de terceros molares retenidos. Int. J. Morphol., 29(2):526-531, 2011.

RESUMEN: Se investigó la inmunodetección de PCNA en los componentes epiteliales de los folículos dentales asociados a terceros molares retenidos sin signos radiográficos y morfológicos de la patología. Fueron extraídos quirúrgicamente, de 56 pacientes, 105 muestras de folículos dentales asociados a terceros molares retenidos con rizogénesis incompleta (entre los estadíos de Nolla 6 y 9) La proliferación de células epiteliales se deteminó mediante inmunohistoquímica. El análisis estadístico se realizó mediante la prueba exacta de Fisher. De los 105 folículos dentales recogidos, 6 fueron PCNA-positivos $(\approx 6 \%)$. Las muestras con metaplasia escamosa e hiperplasia epitelial tuvieron mayores tasas de positividad para PCNA, así como aquellos con restos de proliferación del epitelio odontogénico. En conclusión, este estudio mostró que los folículos dentales en esta etapa del desarrollo tienen un potencial proliferativo bajo, pero sugiere que la metaplasia escamosa, la hiperplasia del epitelio y la presencia de restos epiteliales odontogénicos, en proliferación en el tejido conectivo, pueden ser signos tempranos de lesiones en el desarrollo de origen odontogénico.

PALABRAS CLAVE: Inmunohistoquímica; Saco dental; Tercer molar.

\section{REFERENCES}

Adelsperger, J.; Campbell, J. H.; Coates, D. B.; Summerlin, D. J. \& Tomich, C. E. Early soft tissue pathosis associated with impacted third molars without pericoronal radiolucency. Oral Surg. Oral Med. Oral Pathol. Oral Radiol. Endod., 89:402-6, 2000.
Barboza, C. A. G.; Pinto, L. P.; Freitas, R. A.; Costa, A. L. P. $\&$ Souza, L. B. Proliferating cell nuclear antigen (PCNA) and p53 protein expression in ameloblastoma and adenomatoid odontogenic tumor. Braz. Dent. J., 16:5661, 2005. 
OLIVEIRA, D. M.; SILVEIRA, M. M. F.; ANDRADE, E. S. S.; SOBRAL, A. P. V.; MARTINS-FILHO, P. R. S.; SANTOS, T. S. \& OLIVEIRA, P. L. A. Immunohistochemical analysis of proliferating cell nuclear antigen (PCNA) in dental follicles of impacted third molars. Int. J. Morphol., 29(2):526-531, 2011.

Baykul, T.; Saglam, A.; Aydin, U. \& Basak, K. Incidence of cystic changes in radiographically normal impacted third molar follicle. Oral Surg. Oral Med. Oral Pathol. Oral Radiol. Endod., 99:542-5, 2005.

Cabbar, F.; Güler, N.; Comunog`^lu, N.; Sençift, K. \& Çölog ${ }^{\circ} \mathrm{lu}, \mathrm{S}$. Determination of potential cellular proliferation in the odontogenic epithelia of the dental follicle of the asymptomatic impacted third molars. $J$. Oral Maxillofac. Surg., 66:2004-11, 2008.

Daley, T. D. \& Wysocki, G. P. The small dentigerous cyst. A diagnostic dilemma. Oral Surg. Oral Med. Oral Pathol. Oral Radiol. Endod., 79:77-81, 1995.

de Paula, A. M.; Carvalhais, J. N.; Gallichio Domingues, M.; Barreto, D. C. \& Alves Mesquita, R. Cell proliferation markers in the odontogenic keratocyst: effect of inflammation. J. Oral Pathol. Med., 29:47782,2000

Edamatsu, M.; Kumamoto, H.; Ooya, K. \& Echigo, S. Apoptosis-related factors in the epithelial components of dental follicles and dentigerous cysts associated with impacted third molars of the mandible. Oral Surg. Oral Med. Oral Pathol. Oral Radiol. Endod., 99:17-23, 2005.

El Murtadi, A.; Grehan, D.; Toner, M. \& McCartan, B. E. Proliferating cell nuclear antigen staining in syndrome and nonsyndrome odontogenic keratocysts. Oral Surg. Oral Med. Oral Pathol. Oral Radiol. Endod., 81:21720, 1996.

Glosser, J. W. \& Campbell, J. H. Pathologic change in soft tissues associated with radiographically "normal" third molar impactions. Br. J. Oral Maxillofac. Surg., 37:25960, 1999.

Godoy, G. P.; da Silveira, E. J.; Lins, R. D.; de Souza, L. B.; de Almeida Freitas, R. \& Queiroz, L. M. Immunohistochemical profile of integrins in enlarged dental follicle and dentigerous cysts. Oral Surg. Oral Med. Oral Pathol. Oral Radiol. Endod., 104:29-34, 2007.

Güven, O.; Keskln, A. \& Akal, U. K. The incidence of cysts and tumors around impacted third molars. Int. J. Oral Maxillofac. Surg., 29:131-5, 2000.

Kostopoulou, O.; Brickley, M. R.; Shepherd, J. P. \& Newcombe, R. G. Perceived risk of future pathology associated with pathology-free third molars: A comparison of oral and maxillofacial surgeons and family dentists. Br. Dent. J., 188:28-31, 2000.
Li, T. J.; Browne, R. M. \& Matthews, J. B. Quantification of PCNA cells within odontogenic jaw cyst epithelium. $J$. Oral Pathol. Med., 23:184-9, 1994.

Meer, S.; Galpin, J.; Altini, M.; Coleman, H. \& Ali, H. Proliferating cell nuclear antigen and Ki67 immunoreactivity in ameloblastomas. Oral Surg. Oral Med. Oral Pathol. Oral Radiol. Endod., 95:213-21, 2003.

NHS Centre for Reviews and Dissemination. University Of York. Prophylactic Removal of impacted third molars: is it justified? Effectiveness matters. Br. J. Orthod., 26:149-51, 1999.

Oliveira, D. M.; Andrade, E. S. S.; Silveira, M. M. F. \& Camargo, I. B. Correlation of the radiographic and morphological features of the dental follicle of third molars with incomplete root formation. Int. J. Med. Sci., 5:36-40, 2008

Piattelli, A.; Fiorini, M.; Santinelli, A. \& Rubini, C. Expression of proliferating cell nuclear antigen in ameloblastomas and odontogenic cysts. Oral Oncol., 34:408-12, 1998.

Sousa, F. A. C. G.; Paradella, T. C.; Carvalho, Y. R. \& Rosa, L. E. B. Immunohistochemical expression of PCNA, p53, bax and bcl-2 in oral lichen planus and epithelial dysplasia. J. Oral Sci., 51:117-21, 2009.

Stephens, R. G.; Kogon, S. L. \& Reid, J. A. The unerupted or impacted third molar - a critical appraisal of its pathologic potential. J. Can. Den. Assoc., 55:201-7, 1989.

Correspondence to:

Dr. Emanuel Sávio de Souza Andrade

Faculdade de Odontologia de Pernambuco. Universidade de Pernambuco.

Av. General Newton Cavalcanti, 1650

CEP: 54753-220

Camaragibe - Pernambuco

BRAZIL

Email: thiago.ctbmf@yahoo.com.br

Received: 26-11-2010

Accepted: 26-03-2011 